Lidija Vidmar

Osnovna šola Frana Albrehta Kamnik

lidija.vidmar@os-fa.si
Zbornik povzetkov strokovne konference Spodbujanje učinkovitega učenja, Koper, 26. avgust 2020

Abstracts of the Professional Conference Developing Effective Learning, Koper, 26 August 2020

\section{IKT-orodji v podporo formativnemu spremljanju}

Kahoot! in GoFormative sta orodji, ki učiteljem omogočata popestritev vseh faz pouka (ugotavljanje predznanja, uvodno motivacijo, podajanje nove snovi, utrjevanje snovi), učence pa prek igre na zabaven način spodbujata k zdravi tekmovalnosti in učinkovitemu učenju. Primerni sta tudi za preverjanje in ocenjevanje znanja. Obe orodji lahko uporabljamo na spletu in v aplikaciji. Dostopni sta prek osebnega računalnika, prenosnika, tablice ali pametnega telefona. Učenci za uporabo ne potrebujejo uporabniških imen in gesel, učitelj pa lahko izbira med prosto dostopno ali plačljivo različico. Sestavljene kvize je možno igrati skupaj v razredu ali pa kot izzive z lastnim tempom prek spleta. Obe orodji imata raznolike možnosti zastavljanja vprašanj (kratki ali dolgi odgovori, več izbir, prav ali narobe, določi vrstni red) in sta združljivi z avdio- in videoposnetki ter s slikami. V spletnih učilnicah Microsoft Teams in Google Classroom se lahko sestavljeni kvizi igrajo kar znotraj učilnice. Učitelj lahko sproti spremlja napredek učencev, zbrane analize pa lahko prenese na svoj računalnik v obliki dokumenta pdf ali Excelove tabele. Obe orodji imata strokovno- tehnično podporo in možnost sodelovanja ter izmenjave kvizov z učitelji z vsega sveta. $V$ času pouka na daljavo sta učiteljem obe orodji brezplačno omogočili uporabo vseh funkcij. V prispevku avtorica na konkretnem primeru predstavi obe orodji, udeležencem omogoči pogled učenca in pokaže uporabnost zbranih rezultatov.

Ključne besede: Kahoot, GoFormative, formativno spremljanje

\section{ICT Tools as a Support for Formative Assessment}

Kahoot! and GoFormative are tools which enable a teacher to make all lesson stages (prior knowledge assessment, introductory motivation, new topic presentation, topic revision) more interesting and stimulate effective learning and a healthy measure of competitiveness in students in an entertaining way through a game. They are also suitable for knowledge assessment and evaluation. Both tools can be used online or through an application. They are available on personal computers, laptops, tablets or smart phones. Students do not need user names and passwords and a teacher can choose between the free or payable version of a tool. Previously prepared quizzes can be played together in a classroom or online as self-paced challenges. Both tools offer diverse possibilities for asking questions (short or long answers, multiple choice, true or false, correct order) and can be merged with audio and video recordings, and pictures. In online classrooms $\mathrm{Mi}-$ crosoft Teams- and Google Classroom-prepared quizzes can be played in the online classroom itself. A teacher can supervise students' progress, and the collected analyses can be downloaded to their computer in the form of a pdf document or excel table. Both tools have professional-technical support and have the possibility of cooperation and sharing quizzes with other teachers all over the world. During the period of distance teaching both tools enabled teachers to use all its functions free of charge. In the article, the author presents both tools, including concrete examples, and enables the participants to take a look at the students' view of online classrooms and shows the usefulness of collected results.

Key words: Kahoot!, GoFormative, formative 